\title{
THE MUNICIPAL INSTITUTIONS OF AUSTRALIA
}

\section{WITH SPECIAL REFERENCE TO CONDITIONS IN NEW SOUTH WALES}

The beginning of Municipal Government in Australia dates back to July, 1842 , when an act was passed in New South Wales to declare the town of Sydney (the capital) to be a city and to incorporate the inhabitants thereof.

Under this act, which was the foundation for much of the subsequent legislation, the city of Sydney was divided into six wards, and the council consisted of four councillors elected by the citizens, and six aldermen elected by the councillors, the whole council electing a mayor from among themselves. The only persons entitled to vote for the election of councillors were males of the full age of twenty-one years (other than aliens), who had occupied any house, warehouse, counting-house, or shop within the city at the annual value of $E 25$, clear of all charges thereupon, during the whole of one year preceding such election, provided that no person could vote who had failed to pay his rates. The act also prescribed the mode of voting by requiring that every citizen entitled to vote should deliver to the presiding officer a voting paper containing the names of the persons for whom he voted, such voting-paper being previously signed by the voter, who was also required to fill in his address. Every citizen elected to the office of councillor, alderman, auditor, or assessor, and every councillor elected to the office of mayor, was required to accept the office or pay a fine to the city fund. Persons convicted of bribery in connection with the municipal elections were liable to penalty as well as permanent disqualification. The usual provisions were made for the retirement of a certain number of the council each year, and also for the vacation of office in event of bankruptcy or absence without leave. The council had the entire control of the appointment and remuneration of all the officers, including the town clerk and the treasurer, and also had the power to grant a salary to the mayor "in lieu of all fees, perquisites, and other emoluments." The power of the mayor was exceedingly limited, and he was, in fact, merely the chairman of the council.

Under this act the council was authorized to levy a city rate not exceeding one shilling in the pound per annum on the full, fair, and

$$
\text { [255] }
$$


average annual value clear of all outgoings, of practically every building within the limits of the city, and also a "lighting rate". not exceeding four pence in the pound computed in like manner. It was also empowered to raise a "police rate," not exceeding six pence in the pound on the annual value of ratable property, for the purpose of remunerating a number of special constables who were to be sworn in every year, because the ordinary police force of the city (which was under the control of the government) was insufficient to maintain the peace. In addition, it was given power to regulate the markets and the market wharf, to control the roads within the city, to construct common sewers, drains, and watercourses, public wells and pumps, as it thought necessary; and was also charged with the responsibility for the good rule and government of the city, and for the prevention and suppression of all nuisances, sanitary or otherwise.

For the purpose of carrying out the work devolving upon them, the council was authorized to borrow on the credit of the corporation, by mortgage or otherwise, any sum of money not exceeding the average amount of the revenue of the corporation (exclusive of the police rate) during a period of five years. It was provided, however, that the total debt of the council at any time should not exceed five average years' revenue, exclusive of the police rate and any grant received from government.

A few days after this act of 1842 came into force, the government passed the Appropriation Act, whereby they were empowered to pay to the city fund each year a sum equal to the amount paid by the citizens under the council's assessment, but not exceeding $£_{5,000}$ in any one year.

I have just touched upon the main provisions of this important act, but probably enough has been said to show that even in those early days of municipal government the councillors were intrusted with wide powers and important duties, which, if zealously and intelligently carried out, could not fail to be of the greatest public value. It is not to be wondered at that experience revealed some defects in the first act, and that consequently in October, I85o, Parliament passed a new act for the regulation of the corporation of the city of Sydney. In considering this latter act it will be necessary to look only at the points of difference between it and the earlier measure. 
It is interesting to note that while the qualification of the voters remained practically the same, greater care was taken to insure, by means of revision courts, that every qualified voter should be enrolled, and that names improperly on the roll should be expunged. More stringent qualifications were required for the office of councillor or alderman, to which office no citizen became eligible until he was possessed of real or personal estate, or both, to the amount of $E_{1}, \infty 00$, either in his own right or in that of his wife, or unless he was rated on the annual value of not less than $t i o 0$. Persons elected to these offices were not entitled to hold any office or place of profit under the council, either directly or indirectly.

One important reform effected by this act was the election of mayor, councillors, and aldermen by the citizens, the method of voting being by means of a ballot paper signed the voter. Plural voting was not permitted, as a citizen assessed in respect to property situated in several wards was entitled to vote in only one of them as he might select.

The act also defined bribery or corruption in connection with municipal elections; that is to say:

"The giving of money or any other article whatsoever, cockades included, to any elector with a view to influence his vote, or the holding out to him any promise or expectation of profit, advancement, or enrichment in any shape to influence his vote, or making use of any threat to any voter, or otherwise intimidating him in any manner with a view to influence his vote, treating of any voter, or supplying him with any drink, lodging, or horse or carriage hire, or conveyance by steam or otherwise whilst at such election or whilst engaging in coming to or going from such election, the payment to any elector of any sum of money for acting or joining in any procession during such election or before or after the same, keeping open or allowing to be kept open any public house, booth, or tent, or place of entertainment, whether liquor or refreshment of any kind be distributed at such place of entertainment or not, giving of any dinner, supper, breakfast, or other entertainment in any place whatsoever by a candidate to any number of persons with a view to influencing their votes."

An offence against this section was punishable by a fine of $£ 200$ for each offence, besides disfranchisement for seven years. Principals were bound by the acts of their authorized agents, and persons other than authorized agents found guilty of so offending were liable to be convicted of misdemeanor and punished with fine or imprisonment. Moreover, any voter who received any reward or loan, [257] 
or any consideration whatever for refraining to vote was liable to a penalty of $£_{50}$ for each offence, and to be forever disfranchised.

The powers of the council in respect to sanitation were considerably widened, but the general powers which the original act conferred upon it for the making of by-laws and regulations were limited in so far as such by-laws were to be subject to the approval of the Governor-in-Council. No additional restriction was placed upon the borrowing powers of the council, but the excellent provision was enacted that in order to discharge all loans the council should establish a sinking fund to be invested in government securities.

Unfortunately the municipal control of the city fell into the wrong hands, and so much public dissatisfaction was created that three years later,-viz., in October, 1853,-the Parliament of New South Wales passed the Sydney Corporation Abolition Act, and put the whole municipal control of the city under three salaried commissioners, who held office from the beginning of 1854 to the end of 1857 . In March of this latter year the municipal council of Sydney was re-established with powers practically the same as it had under the previous acts.

Several important developments are revealed in the act of 1857 , among them being the constitution of the council by aldermen only, instead of councillors and aldermen as formerly. The aldermen were elected by the rate-payers, and from among themselves elected the mayor. One rather startling innovation was contained in this act in a brief clause as follows:

"The mayor, aldermen, and auditors shall be entitled to receive for their services out of the city funds such salaries and allowances as the council shall from time to time determine."

The auditors had, of course, always been salaried officials, and it had been customary to grant an honorarium to the mayor, but it is somewhat novel to find the aldermen entitled to pay themselves any salaries they thought fit! Owing doubtless to the increase in the population of the city, the subject of public health had become one of great importance, and the city council was charged with the duty of appointing a qualified medical practitioner as a health officer with power to investigate the origin of diseases and to attend to such matters as the ventilation of buildings, and indeed anything which affected the health of the citizens. 
Up to October, 1858 , the acts relating to municipal government were only those in connection with the city of Sydney to which I have already referred, although in 1843 several of the country districts were incorporated under letters patent into district councils. The act of 1858 was, therefore, the first piece of legislation of any importance dealing with general municipal government.

Under this act the Governor-in-Council was empowered to declare a municipality formed on the petition of not fewer than fifty householders, unless a counter-petition signed by a greater number were received. At the first election all persons having a freehold, leasehold, or household qualification were deemed electors, and at subsequent elections all such persons who were also rate-payers were qualified to vote. If the population of a municipality did not exceed I,, 00 , six aldermen were to be elected, but if the population were greater, the number of aldermen was increased to nine. Among the powers and duties committed to the suburban and country municipalities was the right to erect toll-gates and charge tolls on any road, market, bridge, ferry, wharf, or jetty. They were authorized also to impose a general rate not exceeding one shilling in the pound on the average annual rental value of buildings, and also to levy special rates for water supply, sewerage, and lighting. With the sanction of the Governor-in-Council any municipality could borrow an amount not exceeding the estimated revenue for three years. The government undertook to endow each municipality during the first five years with a sum equal to the amount of the rates actually raised in the year; during the next five years with a sum equal to one-half of the amount so raised, and in each of the next five years one-fourth of the amount raised, after which the endowment should cease.

The next step in the work of municipal legislation in New South Wales was an act passed in July, 1879 , consolidating and amending the laws relating to the corporation of the city of Sydney. This act with the amendments of it was consolidated in August, 1902, and remains in force to-day. I need, therefore, refer only to this latter act by way of illustrating the conditions under which the municipal government of the second largest city in the British Empire (estimated by the annual value of its ratable property) is carried on.

There are several directions in which important amendments on preceding acts are embodied in this latest measure. First, as to the qualifications of citizens, it is provided that any natural-born or 
naturalized British subject, male or female-for the first time women are given a vote-possessed of a freehold interest in property assessed at a yearly value of $£_{5}$ or upward, or of a leasehold interest of a yearly value of $t_{25}$ or upward, is entitled to vote in every ward in which he or she is so qualified. Any British subject who has been continuously during the preceding six months in joint or several occupation of any house, warehouse, counting-house, shop, or other building including any room or part of a house separately occupied in the ward, of a yearly value of $f$ Io or upward, or who, as a lodger, has continuously during the previous six months occupied, jointly or severally, any lodgings in a ward of a clear yearly value of $\ell_{10}$ or upward, is entitled to one vote only. This qualification confers on practically every adult citizen in Sydney who has resided in any one ward for six months prior to an election the right to vote in that ward.

Another, and perhaps the most important, reform effected by this act is in the method of voting, which is by means of a secret ballot. This is so important that I make no apology for quoting from the section of the act as follows:

"Such citizen shall take such ballot papers into an inner compartment, and there without delay cancel them by striking through the name of every candidate except such as he intends to vote for, and shall then fold up each ballot paper so as to conceal the names and immediately put it into the ballot box, and thereupon he shall at once quit such booth or room and shall not re-enter the same during the election.

"No two voters shall be in the same inner compartment at the same time."

The ballot paper is not signed, nor is there anything upon it to indicate the identity of the voter. Ample provision is made for the accommodation of blind or illiterate citizens, and safeguards are provided against impersonation. The greatest possible care is exercised in the supervision and examination of the ballot boxes so as to prevent any ballot papers being taken therefrom or inserted therein, and the examination of the ballot papers is made by the returning officer in the presence of scrutineers, and the result of the ballot is thereupon declared by the mayor.

The money which any candidate for election as alderman is entitled to disburse in electioneering expenses is limited to the sum of $f_{5}$, and the details of such expenditure, verified by statutory declaration, are to be furnished to the town clerk within seven days after [260] 
the holding of an election. If any candidate should spend more than the sum of $£_{50}$, he is liable to a penalty of $\mathfrak{t}_{20}$ and his election is declared void. As in the earlier acts so in the present act, every person holding any place of profit under the Crown or the council, is disqualified from being elected to the office of alderman, and in like manner every person who within three years has compounded with his creditors, and every uncertificated bankrupt or insolvent, is also disqualified. With these exceptions any male person on the roll for any ward of the city shall be qualified to be elected as alderman. The whole of the aldermen are required to retire simultaneously every two years.

The sections of the act which relate to bribery, treating, intimidation, etc., in connection with the municipal elections are the same, mutatis mutandis, as relate to parliamentary elections, and provide that every person guilty of bribery (the definition of bribery is minutely set forth in seven sub-sections) shall be liable to a fine of fioo or to six months' imprisonment or to both, and shall be incapable of voting at such election; and every candidate for election who shall be guilty of "treating" (the definition of which offence is clearly described) shall be liable to the penalty just mentioned. The offence of intimidation is defined as a misdemeanor punishable in a similar way. Moreover, the act expressly provides that:

"No act, suit, or other proceeding whatsoever shall be brought or maintained whereby to charge a person upon any contract or agreement for the loan of money or the doing of any work or service or the supply of any goods for or towards or concerning or in carrying on or in prosecuting any election of a member under this Act,"

and further that:

"Any person who makes or is concerned in any wager, bet or other risk of any nature whatsoever upon the result of any election shall for every such offence be liable to a penalty not being less than $\neq_{5}$ nor exceeding $\neq_{50}$, and every such wager, bet, or other risk shall be and is hereby declared an illegal act."

As in former years the officers of the council are entirely under the control of the council, who fix their remuneration and terms of service. The mayor has the power to suspend any officer or servant of the council, provided that he report the suspension at the next meeting of the council, who shall thereupon confirm such suspen[26I] 
sion or otherwise deal with the matter. The provision in the earlier act which enabled the aldermen to remunerate themselves out of the funds of the council is entirely done away with, and in lieu thereof provision is made that a mayoral allowance may be granted by the council each year. In the city of Sydney this is usually fixed at $t I, 000$ per annum, in Melbourne at $t I, 500$ per annum, and at smaller sums in the other capital cities in Australia. This allowance is spent in civic hospitality, and is usually insufficient to cover the expenses which the office entails upon its holder.

The act of which I have just been speaking refers only to the city of Sydney, as the present law under which the suburban and country municipalities operate dates back to the Municipalities Act of 1867 , which with the amendments thereon was consolidated thirty years afterwards. In almost all the other states of the Commonwealth of Australia there are more or less comprehensive systems of local government in force, but, unfortunately, in the parent state of New South Wales the efforts hitherto made to introduce a local government bill have been frustrated, so that the government remains the one great centre from which every portion of the state seeks to obtain all the financial assistance it requires. Every road, every bridge, and, in fact, every local work of a public character in the country is constructed and maintained at government cost. The existing system cannot be defended on any grounds ethical or political, and its continuance has tended in no small degree to the degradation of politics.

It may be worth while to enumerate briefly the constitution and powers of these suburban and country municipalities. The number of aldermen in each municipality varies from six to twelve according to the population, who are presided over by a mayor elected from among themselves each year. Every rate-payer of the full age of twenty-one years is entitled to vote, and accumulative votes are permitted according to the assessed value of the property occupied, leased, or owned by the rate-payer. Voting is by secret ballot as in the case of city elections, and generally speaking the same ceremonies are observed and the same safeguards exercised as in the case of city elections.

Besides the power to fix rates, these municipalities may borrow up to five times their estimated annual revenue, exclusive of government endowments, for the purpose of building town halls or council [262] 
chambers, or for carrying out any other work within the powers of the municipality. These loans are usually secured by mortgage or debentures, or both, and with very few exceptions are regarded as safe and remunerative investments. A number of the municipalities have erected gas-works and water-works, some of them having constructed municipal baths, and it is lawful for them to erect wharves, jetties, or piers where necessary or convenient.

Every council has power within its municipality to abate and remove all nuisances therein, to order and compel the extirpation of noxious weeds, and to establish tolls on roads, bridges, wharves, etc. As a matter of fact, however, there are no tolls on any roads or bridges, and no rates are levied beyond the general rate and the lighting, water, and sewerage rates.

The entire police force of the state is presided over by the inspector-general of police, and is under the control of the government, so that neither the mayor nor council of any municipality can exercise any authority over them whatever.

The municipalities in Australia take no part in the educative work carried on by means of art galleries, public libraries, and the like, the most important of which are maintained and controlled by the government or by local schools of art. Neither do they conduct charitable organizations, most of the asylums for the blind, deaf and dumb, indigent, and insane being carried on by the government. Numerous organizations for the relief of the poor exist throughout the country, but these are maintained either by charitable, religious, or non-sectarian bodies, and not by the municipalities.

There are many suburban and country districts in New South Wales which are not incorporated into municipalities, but whose interests are looked after by voluntary committees called progress associations, and in one suburb, at least, the residents have cheerfully taxed themselves in order that the progress association might carry out certain local works that were desired.

In the city of Sydney the municipal council has recently entered upon an extensive and costly scheme of electric lighting under the powers conferred upon it by an act of Parliament passed in I896. An admirable site has been selected for the power station, of sufficient area to accommodate machinery and plant equipment developing approximately 30,000 horse-power. Electricity will be generated at 5,200 volts on the three-phase alternating system, with a [263] 
periodicity of fifty cycles. The object of the council is to supply electricity to the citizens of Sydney as economically as possible.

Unlike most of the other capital cities, the streets of Sydney are under a divided control, for although nominally under the direction of the municipal council, certain other bodies have independent powers in connection with them. For example, the railway commissioners carry on their electric tramway system (or street railways) without deference to the municipal council, and maintain at their own cost about one-third of each road-way along which the lines are laid. The metropolitan board of water supply and sewerage (which is practically a governmental department, notwithstanding that the city and suburban municipalities have their elected representatives on the board), and the Australian Gaslight Company and the Sydney Hydraulic Power Company (which are private corporations), each possesses certain powers in the way of opening up the foot-paths and streets for the purpose of carrying on their respective works, which have been granted to them by act of Parliament and outside of the authority of the municipal council. The vehicular traffic of the city is controlled by the police, who, as previously mentioned, are under the direction of the government through the inspector-general.

All the telegraph lines and stations and the telephone systems in Australia are state-owned, and on the establishment of Federation, in I9OI, they were handed over to the control of the Federal government, which, like the state authorities before them, can erect telegraph poles, construct telephone tunnels, and carry out any other necessary work in connection with the department without sanction from the municipal authorities.

Besides these independent bodies there is the board of health, whose powers are exercised by each council within its municipality, and which include the control of noxious trades and cattle slaughtering, and the supervision of dairies. The fire brigades board controls the fire brigades within the metropolitan and suburban area. One member of this board is elected by the municipal council of Sydney, and one by the suburban municipalities within whose boundaries the board operates. The annual outlay for the fire brigades board's maintenance is contributed in three equal shares by the fire insurance companies, the municipal councils of Sydney and suburbs, and the government, respectively. 
In the other capital cities of Australia the municipal councils possess wider powers in many directions than is the case in Sydney, notwithstanding that the latter city is the largest in Australia and the capital of the oldest state. In Melbourne, the capital of the state of Victoria, the street tramways are on the cable system and are the property of a private company. At the end of a certain period of years (having still about fourteen years to run), the council is to take over these tramways at their then value. Somewhat similar schemes have been adopted in Brisbane, the capital of the state of Queensland, and in Perth, the capital of the state of West Australia, where street electric tramways have been constructed by private companies under the authority of the municipalities.

It is not surprising, therefore, that the municipal council of Sydney is seeking to acquire additional powers, which it claims to be entitled to exercise. Two bills have been prepared for submission to Parliament, one of which is to give the council a new building act on modern lines. This act will provide, inter alia, for the streets being vested in and under the control of the council, who shall have civil remedies of the owners of the soil in establishing, maintaining, and defending public rights; for the regulation of the position of gas and water pipes; for the limitation of the height of buildings in crowded districts; for the ventilation of basement floors, and for damp-proof and rat-proof construction of basements; for regulating the construction of house-drains and their ventilation; for power to close all buildings certified as unfit for human habitation; for providing fire-escapes; and generally for powers dealing with the construction and alteration of buildings within the city. A great deal in this direction is already being done by the city surveyor, the city health officer, and the city building surveyor under the limited powers they possess, but if the new bill be passed into law, a much wider scope will be given to the operations of the council.

The other bill is mainly to give the council authority to obtain rates from public boards and trusts,-e.g., the water and sewerage board, and Sydney harbor trust commissioners; and to provide that fees which at present are paid to the government for auctioneers' licenses, liquor licenses, registration of dogs, supervision of dairies, weights, and measures, and licensed vehicles shall be handed over to the city fund.

While it is not unreasonable that the municipal councils of our [265] 
capital cities should claim to be entitled to exercise fuller powers within their boundaries, there are many reasons for supposing that the Parliament of New South Wales, having been shorn considerably of its former glory by the establishment of federation, will now be unwilling to delegate any of its remaining authority to any municipality. We may therefore have to wait the advent of a Greater Sydney scheme, and the consequent establishment of some central council on the lines of the famous London County Council. Certain steps have already been taken towards the creation of a Greater Sydney, but the question can hardly be said to have gone beyond its embryonic stage at present. There are the advocates of unification and of federation who still require to settle their differences, and there are a multitude of other initial difficulties upon which public opinion still remains absolutely uninformed. In this connection I quote a paragraph from the voluminous Annual Report for I902, compiled by the town clerk of Sydney, in which he says:

"The possibilities of Sydney as an ideal municipality are in my opinion large, and this is a fact practically unchallenged and unchallengeable, but this can never be attained or developed until the government and the existing suburban councils actually realize their responsibility in the matter, and are prepared by a spirit of self-sacrifice and self-abnegation to recognize that an ideal city with an ideal city government is a goal to be aimed at by all, irrespective of the internecine conflict engendered by stress of party politics, state or municipal."

The larger spirit which the federation of the Commonwealth of Australia will undoubtedly breathe into the national life of the people will be reflected in their municipal as well as in their political affairs, and it is therefore to be expected that the extension of our municipal activities will be more markedly important in the future than they have hitherto been. Very much yet remains to be done before ideal municipal government is accomplished. Fortunately for Australia, its political and municipal institutions have, on the whole, been hitherto free from those grossly corrupt influences which have wrought such pernicious results in some other countries. The apathy of the public, and the indifference which our leading citizens exhibit towards this important department of local legislation, is mainly responsible for the shortcomings which undoubtedly do exist. The control of affairs has been left in the hands of persons who, however well meaning, are utterly incapable of adequately dis- 
charging the responsibilities of office. The creation of a healthy public opinion, and the recognition that even in this utilitarian age something of the old Roman sacrifice of self for the good of the state is essential to the honest and efficient administration of public affairs, will do much to raise our municipal life to a higher plane. Our best and most capable citizens are so busy attending to their own personal concerns that, while exercising to the full the Britishers' privilege of grumbling, they are slow to recognize, and still slower to accept, any measure of the blame which undoubtedly falls upon them. Notwithstanding this, however, the outline I have given of the development of Australian municipal life exhibits the constant upward and progressive tendencies manifested therein. We are undoubtedly farther advanced to-day than we were twenty years ago, and one may reasonably hope that that silent evolution which is working out its eternal purposes in the social, as truly as in the physical world, will equip us for the achievement of higher things in the future.

Sydney, N. S. W., Australia.

B. R. Gelling. 